\title{
Influence of CEOs Power on Their Compensation
}

\author{
Omamo Anne ${ }^{1, ~ *}$, Peter K'obonyo ${ }^{2}$, Florence Muindi ${ }^{2}$ \\ ${ }^{1}$ School of Business, Jomo Kenyatta University of Agriculture and Technology, Nairobi, Kenya \\ ${ }^{2}$ School of Business, University of Nairobi, Nairobi, Kenya
}

Email address:

omamoann@yahoo.com (O. Anne), pkobonyo@uonbi.ac.ke (P. K’obonyo), florence.muindi@uonbi.ac.ke (F. Muindi)

${ }^{*}$ Corresponding author

\section{To cite this article:}

Omamo Anne, Peter K'obonyo, Florence Muindi. Influence of CEOs Power on Their Compensation. European Business \& Management. Vol. 6, No. 6, 2020, pp. 136-142. doi: 10.11648/j.ebm.20200606.12

Received: November 11, 2020; Accepted: November 23, 2020; Published: November 30, 2020

\begin{abstract}
There is growing concern that over recent decades CEOs tend to earn overwhelmingly more than the average worker. This throws the researchers to question the economic benefit of paying CEOs huge amount of money while we have discouraged workers who may become less productive and therefore lowering the firm profitability. Researchers have taken positions on both sides of the debate over whether the level of CEO's pay is economically justified or is the result of managerial power. This study sought to establish the extent of power that CEO's possess among Kenya firms listed at the Nairobi Securities Exchange. CEO's power was measured in terms of structural power, ownership power, CEO tenure and Board composition. The study used secondary data. Data was collected from 60 firms listed at the NSE. Using a cross sectional design, a regression model was fitted to show the relationship between CEO's power and CEO's compensation. Descriptive and inferential results were obtained. The findings revealed that in the Kenyan context CEO's power does not significantly influence CEO's compensation. CEO's pay is market-determined and reflects the bidding by firms for scarce executive talent. The increase in CEO's pay is due to the rise in incentive compensation that links pay to firm performance and aligns the incentives of managers with those of shareholders.
\end{abstract}

Keywords: CEOs Power, CEOs Compensation, Profitability, Firms, Nairobi Securities Exchange

\section{Introduction}

Power is defined as the ability of one individual to impress authority upon other persons [1]. The description of power in most cases involves the capacity to influence [2]. Power is a resource that leaders in organizations including CEOs use to exert social influence. There are a number of varying definitions of power among organizations that seem to express power in terms of the ability to impress, influence and control upon others [3]. A majority of the definitions do incorporate the capacity of the individuals with to be able to overcome resistance from others. CEOs who have power are the ones who can, from time to time manipulate major decisions in their organizations despite possible resistance that may emerge from board members $[4,5]$. The CEOs may source their power either formally or informally [3]. Leaders have the ability to acquire power over their followers from four key sources. First, they can acquire structural power which is attributed to their official positions in the organizational structure. Secondly, leaders can possess power by owning resources or shares in an organization which is termed as ownership power. The third power base that leaders could possess is expert power which they acquire by virtue of being experts in some field or skill while the fourth source of power is referred to as referent power.

CEOs derive their power from different sources [6]. First, they may have formal authority delegated to them by the board of directors to develop and implement suitable organization strategies on their behalf. Secondly, CEO's power may come from them or their family members owning company stock. Thirdly, CEO's may derive power by having the ability to directly or indirectly influence the compensation committee, board of directors or external consultants. Lastly, CEO'S power may arise due to duality where the CEO doubles up as chairperson to the board.

Although CEO'S are viewed to be most powerful corporate actors, some are more powerful than others. One dimension that brings about differences in the amount of power that a CEO may possess is to the CEO doubling as board chair [7]. This kind of power may be viewed as an indicator of formal 
power. When CEO doubles in overseeing the board, they tend to possess extra influence in excess of the board on a number of issues including control of meetings agenda, the appointment and composition of the board, influencing decisions on compensation levels of directors and equally has the freedom of refusing to share power with other top managers [8]. The CEO'S informal power varies with a number of stock ownership, concentrated external stock ownership, tenure as CEO, and the proportion of members of board appointed in their CEO'S tenure [9]. Although CEO'S exert strong influences over their compensation, the more powerful CEO'S are successful in controlling the process and outcome of compensation determination [8]. CEO'S compensation is largely affected by the corporate governance practices that an organization adopts. These practices seek to trim the CEO'S power so that they do not act in a manner that goes contrary to the needs of shareholder while simultaneously encouraging behaviors which elicit superior economic effectiveness [10]. CEO'S power can be measured using four parameters that include first, division of power among the CEO and the board chair. Secondly, through presence of owners and managers. Thirdly, CEO'S power can be measured through board constitution utilizing the fraction of self-governing directors and lastly, they could have power by percentage of shares they own in the organization [10].

\section{Literature Review}

According to literature, in a situation where the members of a board have a week power, the CEO will possess greater power in influencing the amount and components of their compensation. This leads to the CEO being overly paid and can get away with poor performance [11, 12]. Design and implementation of CEO compensation is broken by governance failures, where CEO'S are overpaid since they possess power in excess of the board members [11]. The board is charged by shareholders with the responsibilities of monitoring organizational executives and also has an influence in designing and implementing the CEO'S compensation. In some cases the independent directors and consultants who are brought on board to give advice to the board of directors have minimal or completely lack attention in protecting shareholder interests. It grants CEOs power for effectively manipulating their own remuneration and hence distorting CEO compensation contract.

When corporate governance of an organization is seen to be weak, the CEO'S will possess the power to manipulate the amount and composition of their own compensation packages [13]. This may give way to the CEO'S being overpaid and covered against an organization poor performance thereby weakening the association among organizational performance and CEO'S compensation. When CEO'S have power their associated board of directors they tend to be overpaid. Board members have the mandate to monitor CEO'S on behalf of shareholders and they equally have significant influence over the CEO'S compensation committees.

A lot of literature works links CEO'S compensation to board members [14]. Board members are a significant factor in deciding CEO'S compensation levels through the use of internal control mechanism [15]. Members of boards have the responsibility of controlling the future projects of an organization and in making decisions on CEO'S succession [16]. Board members are expected to represent organizations shareholders and protect their interests. Compensation of CEO'S rises as board size expands [17]. Larger boards offer higher compensation to CEO'S [18]. They justify their argument by saying that if an organization requires external resources for its operations like meeting its budget or externally sourced funding, then it implies that the board should be large. Besides, when the processes of governing the organization are complex, it will demand for more knowledgeable thus adding up to reasons of need for the expansion in the number of board members [19]. As a counter proposal it is suggested that smaller boards are more advantageous [20]. Larger boards of directors tend to be ineffective in the sense that they can be effortlessly swayed with CEO [20]. If the board is large, the members hardly reject the policies proposed by the CEO or even objectively evaluate their performance, instead they might protect the CEO'S from reports of poor organizational performance [21].

In recent researches, power of the CEO has attracted considerable interest [22]. The balance of power among organizations, shareholders and CEOS is deemed as a significant cause to the explanation of their relationship. Agency theory explains that the power balance amid shareholders and CEOS builds a driving force in CEO remuneration determination. As explained by agency theorists, CEO compensation is a matter of principal-agent relationship. It is asserted that a major agency problem facing shareholders of organizations is that of moral hazard in which CEO'S may manipulate the use of organizational resource to achieve their own individual interests [1]. It is also argued that the power balance among the CEO'S and their associated members of board form a strong force that influences CEO remuneration [6]. CEO'S ownership or shareholding is a major power driver for the CEO to exercise control on remuneration [23]. This implies that CEO'S will attempt to get more power by having ownership in the organization through acquisition of stock options. However, in as much as CEO'S may utilize the power acquired to maximize their own profit without regard for the shareholders interest, in some cases they might actually use their power in direction that will increase organization performance since the CEO'S personality traits also influences how they use their power. CEO'S who feel that they are being overpaid will find ways of increasing their effort to produce more quality work so as to justify their high levels of compensation [24]. The structural ownership of business organizations will determine the extent to which the organizations are controlled by the CEO'S or by shareholders [25]. When CEO'S have power, they will not develop a feeling of inequity [1]. But overpaid CEO'S react to inequity if their power is low and they will possibly enhance organizational performance unlike CEO'S with high power. This indicates that CEO'S whose compensation needs are 
being met will strive to acquire more power and will enhance their effort to increase organizational performance which in turn may win shareholder's trust.

Much of empirical evidence that supports the managerial power approach in explaining CEO remuneration argues for CEO remuneration having high connection to their ability to capture the board or due to weak corporate governance. The introduction of new standards on board independence in early 2000's was due to corporate scandals among US CEO'S compensation [26]. Organizations whose boards have large number of stakeholders and as such have stronger monitoring powers, tend to closely link CEO'S compensation to organizational performance [27].

Increase in CEO'S compensation is attributed to stricter corporate governance, larger number of shareholders and improved monitoring role by boards over the CEO'S actions. Increase in monitoring intensity negatively influences the stability of the CEO'S job and as such, firms respond by increasing the CEO'S compensation levels [28]. Critics of the managerial power theory on the increase in CEO'S compensation argue that it has fallen short of providing explanations to steady growth in CEO compensation since 1970's. Few studies confirm the proposition of "corporate governance" having a destabilizing effect [29]. In fact several indications suggest that effectiveness of corporate governance has significantly been enhanced [29, 30].

CEOS by nature of their position act to meaningfully increase firm value and are in a unique position that may provide them the opportunity to extract 'rents' [27]. Managers are able to gain ground by making investments that are in line with their needs satisfaction making it difficult for shareholders to replace them [31]. CEO'S can effortlessly have control over their boards and in effect set their own pay which is determined more by managerial power [11]. They adopt a managerial power approach in explaining relationships between power and pay. The approach proposes for "sensitivity of pay to performance" being higher or lesser in organizations in which managers possess adequate authority. The approach further argues that authority of managers broaden in situations where board authority is low, or when the percentage of institutional shareholders is small and lastly when the anti-takeover contracts provides a shield to managers.

Although CEO'S are regarded as the most powerful actors in their organizations, some CEO'S are more powerful than others. CEO'S may pose formal power by virtue of also being "board chairs" [7]. If this holds, then the CEO would have power in excess of the board with responsibilities including "agenda control, director compensation, and committee appointments and equally enjoy the freedom of not sharing power with other top executives". CEO'S also have informal power which they derive from a number of factors and situations including differences in political savvy and CEO'S stock ownership [9]. High percentage of external stock ownership leads to CEO'S occupancy and the fraction of board members installed after the CEO [28]. CEO'S with strong power will be more successful in controlling both the process and outcome of the determination of CEO'S compensation.

Power tends to corrupt and absolute power corrupts absolutely [32]. However the notion that exertion of power is inherently negative is an overly narrow perspective. Negative, adverse and sometimes disastrous results can emanate from the exercise of power though power equally has the ability to elicit positive consequences. Managers including CEO's or organizations can do something with and about power [32]. In line with this argument, CEO's can opt to apply the power in their possession to influence decisions over their compensation.

Leaders draw their power from five major bases [33]. These include legitimate, reward-oriented, coercive, expert and referent basis. This study focuses on the reward form of power. This is the power that a leader possess by virtue of having control over the rewards that someone else desires or needs. In this case, board of directors have the power to influence the level of rewards that CEO's receive. Such that, if the CEO can find ways of swaying the power of the board, then they are likely to influence their own reward levels.

CEO'S compensation tends to escalate with a comparatively powerless board that lack influence over the CEO. CEO remuneration is greater in situations where first, there is higher proliferation of "board members" hence making it difficult for members to organize and collude in support of the CEO. Secondly, existence of broad external directors installed after CEO, may arouse a feeling of appreciation or "I owe you" towards CEO [34]. Thirdly, external directors serving on more than one board, causes them not to pay keen attention on their monitoring role over the CEO. CEO doubling up as "board chair" escalates their rewards by $20-40$ percent $[35,36]$.

A major source of power that CEO'S have in influencing their compensation comes from their ownership or shareholdings [36]. CEO'S strive to gain higher power through acquisition of more stock options hence claiming ownership to the organization. CEO'S power is also attributed to the formal position given to them by the shareholders to make higher level decisions. CEO duality is considered to be another source of their power. This basically implies that the organization's CEO doubles up as the chairperson of "board of directors" [37]. CEOs with high power don't necessarily respond toward reward inequity [1]. However, overly paid CEOS react to inequity when they feel they are powerless and will be motivated to increase firm performance. This implies that CEO'S will strive to acquire power when their compensation needs are satisfied and will work even harder to enhance organizational performance in order to gain confidence of shareholders.

The existence of a large percentage of external shareholders will lead to tighter monitoring of the CEO'S actions and in turn result in the reduction of the CEO'S control over their compensation [31]. In agreement to this examination, it has been found a negative link exists for shareholders who own a large fraction of the organization and CEO reward equity [38]. Enhancing the ownership percentage of the external 
shareholder may reduce the level of other components of compensation. CEOs in organizations with a small percentage of external shareholders tend to explain high CEO'S pay levels from a "luck-based" pay perspective [39]. That is, CEO'S compensation is largely attributed to rise in profits which are mainly generated by external factors as opposed to executives' efforts [39]. Additionally, there exists a high connection among firms with small percentage of external shareholders and increased option-based forms of rewards by a larger percentage than the cash components of compensation [39].

The view of rent extraction proposes that where corporate governance is weak and boards are compromised, the CEO'S will acquire the authority to direct decisions on their rewards and in turn leads to unjustified increases to CEO reward levels. This is presented in managerial power theory [40]. This theory holds that a large portion of rent that CEO'S extract from organization are through elements of compensation that are less obviously visible or are not easy to value like stock options, perquisites, pension and time-off with pay. In equilibrium markets, rent extraction thrives since firing CEO'S is costly and equally replacing them may also extract rents [41]. When the percentage of institutional shareholders is high, it leads to tighter observation and inspection of CEO activities and the board. An inverse association exists among higher concentration of institutional ownership and executive compensation [42].

\section{Methodology}

The research design that was adopted for this study was cross-sectional design, which involved identification and description of phenomena or characteristics linked with a subject population (who, what, when, where, and how of a topic). The approach helped to reveal if any associations exist between the different variables, so as to establish if the variables are independent (or unrelated) and if there is no association, then to establish the strength or magnitude of the relationship. Questions for measuring organizational performance and CEO'S power were carefully selected, arranged and accurately asked of each board member. Cross-sectional studies are conducted once or at one point in time [43].

A cross-sectional design enabled the researcher to establish any relationships between CEO'S power and CEO'S compensation of firms listed in NSE. Data was collected for the period 2016/2017 and 2017/2018. The design was chosen considering the type of data.

The population of the study encompassed all listed organizations at NSE. According to the NSE Handbook 2016, the total number of companies listed at the browse was 65 . This study was therefore a "census survey" meaning the study involved all listed companies. Data on compensation was obtained from financial reports filed with capital markets authority (CMA).

Both primary and secondary data were collected and used in the test of hypotheses. Primary data was collected on the non-financial aspects of organizational performance and CEO'S power through a semi-structured questionnaire. The questionnaire was administered by the researcher- to the firms' board of directors with assistance from the company secretaries who are also the secretaries to the boards. The questionnaire was structured on "Likert-type statements anchored on five-point rating scale ranging from none (1) to very great (5)". This approach had been applied in related studies like [44-46]. Data triangulation was then performed in order to analyze the primary and secondary data obtained.

Data was analyzed using descriptive statistics so as to illustrate key features of the variables of interest in the study. "Mean scores" and standard deviations were computed for Likert type questions and results presented in form of tables. Pearson's "Product Moment Correlation" (r) analysis was used to evaluate the strength and direction of relationships among study variables. "Coefficient of determination $\left(\mathrm{R}^{2}\right)$ was used to measure the amount of variation" in CEO'S compensation due to the predictor variable.

\section{Results and Discussions}

\subsection{Visualization of CEOs Power vs CEOs Compensation}

In order to visualize the relationship between CEO's power and CEOs compensation figure 1 was obtained.

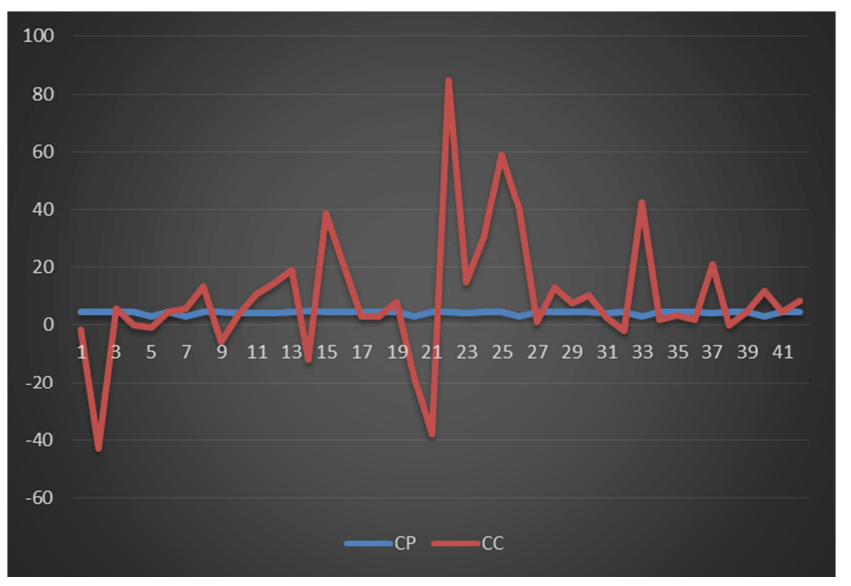

Figure 1. Graph of CEOs power vs CEOs compensation.

The results of figure 1 show that there are variations in CEOs compensation irrespective of CEOs power. This could mean that CEOs power does not significantly influence changes in CEOs compensation. Descriptive analysis of CEOs power were then obtained and the results presented in table 1 .

Table 1. Descriptive analysis of CEOs power.

\begin{tabular}{|c|c|c|c|c|}
\hline Description of CEO's power & $\mathbf{N}$ & Mean & Standard deviation & CV (\%) \\
\hline The CEO is also the chair of the board & 42 & 4.7500 & 0.70711 & 14.88653 \\
\hline
\end{tabular}




\begin{tabular}{|c|c|c|c|c|}
\hline Description of CEO's power & $\mathbf{N}$ & Mean & Standard deviation & CV (\%) \\
\hline The CEO of the company owns majority shares of the company & 42 & 3.8000 & 1.01779 & 26.78395 \\
\hline CEO influences the appointment of external board members & 42 & 4.7000 & 0.46410 & 9.874468 \\
\hline The number of times the current board has revised the CEO'S compensation upwards & 42 & 4.1500 & 0.94868 & 22.85976 \\
\hline $\begin{array}{l}\text { The number of times that the CEO has successfully negotiated with the board for } \\
\text { improvements in his/her compensation package }\end{array}$ & 42 & 3.9500 & 1.15359 & 29.20481 \\
\hline Length of period current board has served contribute to CEO's Power & 42 & 4.325 & 0.4743 & 10.9647 \\
\hline Average score & 42 & 4.270 & 0.8583 & 20.1007 \\
\hline
\end{tabular}

The results in Table 1 provide an average "mean score" of 4.270 on CEO'S power. Since the likert scale was from a scale of 1 (To a very large extent) to 5 (No at all), this indicates that the extent to which the CEO had power was low. On the item of how frequently the CEO chairs the board meetings, board members agreed that it did not contribute at all in determining CEO'S compensation (Mean 4.75, SD 0.70711) implying that CEO's duality does not exist among firms listed at the NSE hence limiting the CEO's power to influence the board over their compensation decisions. The results indicated that board members disagreed that the portion of shares owned by the CEO contributes to CEO's power (Mean 3.8, SD 1.01779). Board members also indicated the percentage of external board members was none contributory at all in determining CEO'S compensation (Mean 4.7, SD 0.46410). The results indicated that board members disagreed that the frequency with which the board turned down the CEO request for revision of compensation contributed to CEO's power (Mean 4.15, SD 0.94868). The results also indicated that board members disagreed that the number of times the CEO has successfully negotiated with the board for improvements in compensation contributed to CEO's power (Mean 3.95, SD 1.15359). The results indicated that board members disagreed that length of period current board has served contributed to CEO's power (Mean 4.325, SD 0.4743). The findings generally indicate that the CEO's do not have power to influence decisions of their compensation.

\subsection{Descriptive Analysis of CEO'S Compensation}

The results were presented in table 2 .

Table 2. Descriptive analysis of CEO'S compensation.

\begin{tabular}{llll}
\hline & & Frequency & Percent \\
\hline & $<1 \%$ & 11 & 26.2 \\
\multirow{3}{*}{ Valid } & $1-5 \%$ & 10 & 23.8 \\
& $6-10 \%$ & 5 & 11.9 \\
& $>10 \%$ & 16 & 38.1 \\
& Total & 42 & 100.0 \\
\hline
\end{tabular}

The study sought to investigate the percentage change in CEOs compensation between 2016/2017 and 2017/2018. Findings revealed that the CEOs compensation for $26.2 \%$ of the firms changed by less than $1 \%$, it increased between $1-5 \%$ for $23.8 \%$ of the firms, it increased between $6-10 \%$ for $11.9 \%$ of the firms and the majority of the increase was over $10 \%$ for
$38.1 \%$ of the firms.

\subsection{Inferential Analysis of CEOs power and CEOS Compensation}

The results were presented in table 3 .

Table 3. Inferential analysis of CEOs power and CEOs compensation.

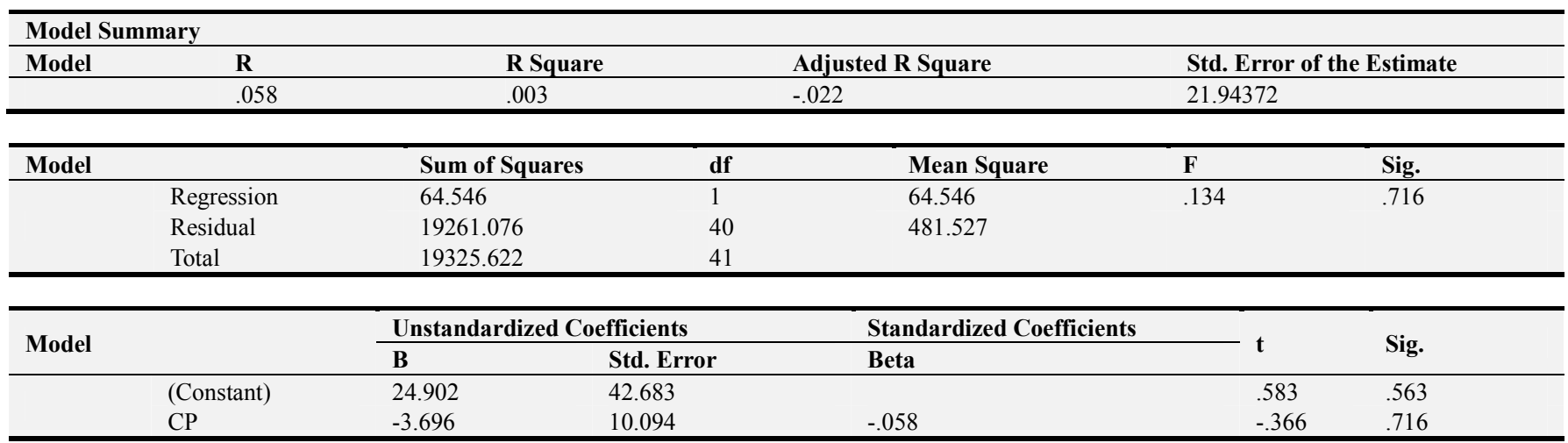

Table 3 presents regression results of the influence of CEOs power on CEOs compensation.

The findings reveal an insignificant effect of CEOs power on CEO'S compensation $\left(\mathrm{R}^{2}=0.003, \mathrm{~F}=0.134, \mathrm{P}>0.05\right)$. This suggests that $0.3 \%$ of changes in CEO'S compensation was due to variation in CEOs power. The table further reveals that beta coefficient was not significant $(\beta=-3.696, t=-0.366$, $\mathrm{P}>0.05)$. This suggests that CEO'S compensation varies by -3.696 units for every unit change in CEOs power. However this variation is not significant. This study's objective was to 
establish the influence of CEOs power on CEO's compensation. Since the influence appears not significant it therefore means the hypothesis that CEOs power influences CEOs compensation is rejected.

The overall model was presented as

$$
C C=24.942-3.696 C P
$$

\section{Conclusions}

The consequences of CEOs power do not seem to have implications on CEO's remuneration. However, the debate on the need for justification of the continuous rise in CEO'S compensation among scholars is far from over. Previous studies on CEO'S compensation reveal a significant link among organizational performance and CEO'S compensation [21]. However the studies done in the Kenyan context focused generally on executive remuneration and its relation to organization performance $[14,48]$. This study reveals that there exists no significant relations among remuneration of executive and compensation. Results of this study also reveal that indeed board members significantly consider organizational performance when revising CEO'S compensation. The study further reveals that CEO power has insignificant effect on CEO remuneration. This is largely attributed to requirements of CMA for listed firms that limits the CEO'S power hence their influence on compensation decision. This is of importance to other firms that may not be listed to benchmark of organizational governance principles. The study faced two main limitations. The first limitation had to do with the sample. While the study had hoped to collect data from the 60 firms listed at the NSE, it only managed to collect data from 40 firms; thus $64 \%$ of the total sample size. The findings therefore may not be generalized across all the firms.

The second limitation arose from the susceptible character of the study that required disclosure of the level of CEO remuneration. Most of the board members were not willing to disclose the actual figures of the CEO'S compensation as was intended. This resulted in review of the questionnaire to instead ask for percentage increase in compensation. The actual figures of compensation would have provided more precise measure of the CEO remuneration and may have improved its relationship with the predictor variable.

This study only captured data for 40 listed firms at NSE that had a total of 65 firms at the time the study was conducted. Future researchers may consider expanding the sample size of the study to include all the firms listed at NSE to increase generalizability of results across the firms. CEO compensation raise was measured using percentage increase of compensation from one year to another. However future studies could use the actual figures of CEO remuneration to be more precise if the information is accessible.

\section{References}

[1] Fong, E. A. (2004). 'Chief Executive Officer (CEO) Responses to CEO Compensatin Equity.' University of Florida.
[2] Steers, R. M, Porter, L. W. and Bigley G. A, (1996). Motivation and Leadership at work, $6^{\text {th }}$ Ed., McGraw Hill.

[3] Pfeffer, S. and Weintrop, J. (1992). Corporate Performance and CEO turnover: A comparison of performance indicators, Administrative Science Quarterly, Vol. 36.

[4] Izan, H. Y., Sidhu, B. and Taylor, S. (1998). Does CEO pay reflect performance? Corporate Governance: an International Review, 6, 39-47.

[5] Kimberly, J. R. (1976), Organizational size and structuralist perspective: A review, critigue and proposal, Administrative science quarterly, 21 (4) 571-597.

[6] Finkelstein, S. and Hambrick D. C., (1989). Chief Executive Compensation: a study of the intersection of markets and political processes, Strategic Management Journal Vol. 10.

[7] Harrison, J. R., David, L. T. and Sal K. (1998). The changing of the Guard: Turnover and Structural Change in teh Top-Management position. Adminstrative Sceince Quarterly 33: 211-232.

[8] Elhagrasey, G., Harrison, R. and Buchholz R. (1999). Power and Pay. The politics of CEO compensation, Journal of Management and Governance. Vol. 3: 213-251

[9] Allen, M. P. (1981). Power and Privilege in the Large Corporation. Corporate Control and Managerial Compensation. American Journal of Sociology 86: 1112-1123.

[10] Parthasarathy, A., Menon, K. and Bhattacherjee, D. (2006), Executive Compensation, Firm Performance and Governance, Economic and Political Weekly.

[11] Bebchuk, L. A., and Fried, J. M, Walker, D. (2002). Managerial power and rent extraction in the design of executive compensation, University of Chicago Law Review, Vol 69, pp 751-846.

[12] Bertrand, M. and Sendhil, M. (2003). Enjoying the quiet life? Managerial behavior following anti-takeover legislation, Journal of political economy, Vol 11, pp 1043-1075.

[13] Sigler, K. J. (2011). CEO Compensation and Company Performance. Business and Economics Journal, Volume 31.

[14] Tarus, K. E., Basweti, A. K. and Nyaoga, B. R. (2014). The Relationship between Executive Compensation and Financial Performance of Insurance companies in Kenya, Research Journal on Finance and Accounting, Vol. 5 (1), 113-122.

[15] Boyd, B. K. (1994). 'Board Control and CEO Compensation.' Strategic Management Journal, Vol. 15, No. 5. Pp. 335-344.

[16] Reed, R., Lemak, D. J. and Mero, N. P. (2000). Total quality management and sustainable competitive advantage. Journal of Quality Management, Vol. 5 No. 1, 5-26.

[17] Guest, M. P. (2009). Board Structure and Executive Pay: evidence from the UK. Cambridge Journal of Economics, vol 31 .

[18] Core, J. E,, Robert, W. H. and David E. L. (1999). Corporate Governance, Chief Executive Compensation and Firm Performance. Journal of Financial Economics, 51: 3, pp. 371-406.

[19] Deckop, J. R. (1988). 'Determinants of Chief Executive Officer Compensation.' Industrial and Labor Relations Review, Vol. 41, pp. 215-226. 
[20] Jensen, M. C. (1986). Agency Costs of Free Cash flow, Corporate Finance, and takeovers. American Economic Review, Vol. 76, pp. 223-229.

[21] Kubo, K. (2001). The Determinants of Executive Compensation in Japan and the UK. Working paper series, No. 2001-2, Institute of Economic Research Hitotsubashi University.

[22] Shah, S. Z., Javed, T. and Abbas M. (2009). Determinants of CEO compensation, Emperical Evidence from Pakistani Listed Companies, International Research Journal of Finance and Economics.

[23] Sapp, S. G. (2007). The impact of Corporate Governance on Executive Compensation.

[24] Agrawal, A. and Charles, R. K. (1998). Managerial Compensation and the treat of Takeover. Journal of Financial Economics, 47: 2, pp. 219-39.

[25] McGuire J. W., Chiu J. S., Elbing A. O. (1962). 'Executive Incomes, Sales and Profits.' The American Economic Review, Vol. 52, pp. 753-761.

[26] Chalmers, K., Koh, P. S., Stapledon, G. (2006). 'The determinants of CEO compensation. Rent extraction or labor demand?' The British Accounting Review 38, 259-275.

[27] Collingwood, H. (2009). DO CEO'S matter? June 25009 Atlantic Magazine, on line Edition.

[28] Hambrick, D. C., and Mason, P. (1984). Upper echelons: The organization as a reflection of its top managers, Academy of Management Journal, 14: 401-418.

[29] Holmstom, B. and Kaplan S. (2003). The state of US Corporate governance: What's right and what's wrong? Journal of Applied Corporate Finance, Spring: 8-20.

[30] Holmstom, B. and Kaplan S. (2001). Corporate governance and merger activity in the United States: making sense of the 1980's and 1990's, Journal of Economic perspective, Vol 15, pp 121-144.

[31] Shleifer, A. and Vishny, R. (1997). Management Entrenchment: The case of Manager Specific Investments, Journal of Financial Economics, Vol 25-123-139. McGRAW-Hill.

[32] Catlin, G. E. G., (1962). Systemic Politics, University of Toronto, Toronto.

[33] Frydman C. and Jenter D. (2015). CEO Compensation, working paper. Stanford University.

[34] Healy, P. (1985). The effect of bonus schemes on accounting decisions, Jounal of Accounting and Economics, Vol. 7, pp. 85-107.

[35] Cyert, R., Sok-Hyon, K. and Praveen, K. (2002). Corporate Governance, Take-overs, and Top-Management Compensation: Theory and Evidence. Management Science. 48: 4, pp. 453-69.

[36] Hubbard, G. (2009). Measuring Organizational Performance: Beyond Triple Bottom Line. Business Strategy and the Environment. Vol. 18 pp. 177-191.

[37] Reich R. (1998). The new meaning of corporate social responsibility, Asian Business and Management, Vol 4: pg. 95-115.

[38] Khanna, V. (2016). Determinants of CEO Compensation, International Journal of Management Excellence, 6 (2).

[39] Leonard, J. (1990). Executive pay and Firm Performance, Industrial and labour relations review, Vo. 43, pp 13-29.

[40] Bebchuk, L. A., and Fried, J. M. (2004). Executive Compensation as an Agency Problem, Journal of Economic Perspective, Vol. 17.

[41] Kerr, J. and Bettis, R. A. (1987). Boards of Directors, top management compensation and shareholder returns, Academy of Management Journal, Vol 30: 645-664.

[42] Himmerlberg, C. P. and Hubbard, R. G. (2000). Incentive pay and the market for CEO's. An analysis of pay-for performance sensitivity, Working paper, Columbia university.

[43] Cooper, D. R. and Schindler, P. S. (2008). Business Research Methods, $10^{\text {th }}$ Edition.

[44] Lambert, R. A., Larcker, D. F., and Weigelt, K. (1991). 'How Sensitive is Executive Compensation to Organizational Size?' Strategic Management Journal, Vol. 12, pp. 395-402.

[45] Ongore, V. (2008). The Effect of Ownership Structure Board Effectiveness and Managerial Discretion on Performance of listed Companies in Kenya, unpublished PhD Thesis, UoN.

[46] Chung, Y. (2010. CEO Ability, Pay, and Firm Performance. JEL Classification: G34, J24, J33.

[47] Jones, D. C., Kato, T. (1996). 'The determinants of chief executive compensation in transitional economies,' Evidence from Bulgaria.' Labor Economics. 3, 319-336.

[48] Aduda, J. (2011). The Relationship between Executive Compensation and Firm Performance in the Kenyan Banking Sector, Journal of Accounting and Taxation, Vol. 3 (6), 130-139. 